\title{
Sigorta Ürünlerinin Dijital Pazarlamaya Etkisi Üzerine Bir Araştırma ${ }^{1}$
}

\begin{abstract}
DOI: 10.26466/opus.558980
*

Hakan Özcan * - Gökhan Demiral**

* Dr.Öğr.Üyesi, Istanbul Okan Üniversitesi, İşletme ve Yönetim Bilimleri Fakültesi, Tuzla/İstanbul E-Posta: hakan.ozcan@okan.edu.tr ORCID: $\underline{0000-0002-4000-9830}$ ** Y.L Öğrencisi, Istanbul Okan Üniversitesi, Sosyal Bilimler Enst., Mecidiyeköy/İstanbul E-Posta: gokhandemiral74@hotmail.com ORCID: $\underline{0000-0002-8982-5425}$ Öz

Gelişen ve değişen teknoloji hayatımızın her alanında etkin olarak kullanılmaya başlanmıştır. Ülkemizde ilaç sektörü de global değişmelere paralel olarak gelişim göstermiştir. Sosyal iletişim ağlarının kullanımının artması ile pazarlama ve satış teknikleri açısından yeni firsatlar ortaya çıkmıştır. Ülkemizde tıbbi ürünlerin dijital ortamlarda satılması ve reklamı yapılması yasaktır. Ancak takviye ilaçları ve bitkisel tıbbi ürünler pazarlayan işletmeler dijital pazarlama ile satış yapmayı hedeflemektedir. Bu çalışmada dijital pazarlamanın ilaç sektöründe etkin bir şekilde kullanılması için neler yapılması gerektiği araştırılmıştır. Pazarlama sürecinde sigortanın etkisi ve sigorta ürünlerinin kullanımı analiz edilmiştir. Dijital pazarlamanın etkin kullanılması için bir dizi teşviklere ihtiyaç olduğu tespit edilmiştir. Kullanıcıların puan, giyim çeki, prim ve tatil ile ödüllendirilmesi beklentiler arasındadır. Online ürün satışı yapan firmalar müşterilerine satınalma miktarına göre verilecekleri puanlama ile; sigorta hizmeti alternatifini sunabileceklerdir. Kullanıcılara sağlık, hukuk, konut, işyeri ve araçları konusunda sigorta asistans ve bilgi hattı hizmetleri sunulabilecektir. Dijital platform üzerinden satın alınan ürünler için sigorta yapılması da sürece olumlu katkı sağlayacaktır. Sipariş edilen ürünün hasarl teslim alınması riski, bu tip pazarlamanın gelişimindeki en önemli bir engellerden biridir.
\end{abstract}

Anahtar Kelimeler: Sigorta, İlaç Sektörü, Dijital Pazarlama

\footnotetext{
${ }^{1}$ Çalışma Dr.Öğr.Üyesi Hakan ÖZCAN, danışmanlığında Gökhan DEMiRAL tarafından Istanbul Okan Üniversitesi, Sos.Bil.Enstitüsünde "ilaç Sektörünün Dijital Pazarlamaya Geçişte Mevcut Alışkanlıklarının Yeni Sisteme Adaptasyonu Üzerine Araştırma" başlığı ile tamamlanmış tezin genişletilmiş ve revize edilmiş halidir.
} 


\title{
A Study on The Effect of Use of Insurance Products on Digital Marketing
}

$*$

\begin{abstract}
Developing and changing technology has been used effectively in every aspect of our life. The pharmaceutical sector in our country has also developed in parallel with global changes. With the increasing use of social networks, new opportunities have emerged in terms of marketing and sales techniques. In our country, it is forbidden to sell and sell medical products in digital media. However, companies that market reinforcement medicines and herbal medicinal products aim to sell with digital marketing. In this study, it has been researched what should be done in order to use digital marketing effectively in pharmaceutical industry. The impact of insurance on the marketing process and the use of insurance products were analyzed. A number of incentives have been identified for the effective use of digital marketing. It is expected that users will be rewarded with points, clothing checks, premiums and holidays. The companies that sell online products will be given to customers according to the amount of purchase by scoring; provide insurance service alternative. We will be able to provide insurance assistance and information line services to users on health, law, housing, workplace and vehicles. Insurance for products purchased through the digital platform will also contribute positively to the process. The risk of receiving a product in a damaged manner is one of the most important obstacles in the development of this type of marketing.
\end{abstract}

Keywords: Insurance, Pharmaceutical Industry, Digital Marketing 


\section{Giriş}

Teknolojinin gelişmesi ve dünya nüfusunun artmasına paralel olarak toplumun ihtiyaç ve beklentileri de değişmiştir (Ercan ve Top, 2016, s.1-7). Gelişen ve değişen teknoloji hayatımızın her alanına girmiş ve etkin olarak kullanılmaya başlanmıştır. Bunun sonucunda da dijital platformlar ön plana çımıştır.Ülkemizde ilaç sektörü de global değişimlere paralel olarak değişim göstermiştir. Sosyal iletişim ağlarının kullanımının artması ile pazarlama ve satış teknikleri açısından yeni fırsatlar ortaya çıkmıştır. Mobil cihazlar ile müşteriler satın almak istedikleri hizmet ya da malın kaynağına hızlı bir şekilde ulaşabilmektedir. Üreticiler de mesajlarını direkt tüketicilere ileterek satınalma davranışlarında etki yaratabilmektedirler (Kaya, 2009).

Ülkemizde "Beşeri Tıbbı Ürünlerin Tanıtım Faaliyetleri“ yönetmelikle düzenlenmiştir (Resmi Gazete, 2015, s.29405). Yönetmelikte “Ürünlerin halka açı tüm mecralarda, internet gibi iletişim ile medya ortamında film, haber program, dizi film ve benzeri yollarla direkt ve endirekt olarak topluma tanıtımı yasaklanmıştır. Pazara ilk kez sunulan ürünlerin dergi/gazete ilanları ve bitkisel tıbbı ürünlerin satışı bu kapsam dışında bırakılmıştır. Bu sınırlar içerisinde bitkisel tıbbı ürünler pazarlayan işletmeler; dijital ortamlarda gerçeğe yakın faaliyetler gerçekleştirmektedir. Bu ortamları hedef kitleleriyle uzun dönemli değişim ilişkileri yaratmaya, sürdürmeye ve geliştirmeye yönelik bir araç olarak kullanmayı hedeflemektedir.

Nüfus sayısının artması, beklenen yaşam süresinin uzaması, nüfusun sosyo- demografik özelliklerinin değişmesi, yaşam koşullarının farklılaşması ve ekosistemin bozulması; karşılaşılan sağlık sorunlarının çeşitlenmesine neden olmuştur. Bu aşamada ilaç sektörünün hayat standartlarının yükseltilmesinde ve sağlıklı bir ömür sürdürülmesinde önemli bir yeri vardır. Bu çalışmada dijital pazarlamanın ilaç sektöründe etkin bir şekilde kullanılması için neler yapılması gerektiği araştırılmıştır. Pazarlama sürecinde sigortanın etkisi ve sigorta ürünlerinin kullanımı analiz edilmiştir.

Dijital pazarlamanın etkin kullanılması için bir dizi teşviklere ihtiyaç olduğu tespit edilmiştir. Kullanıcıların puan, giyim çeki, prim ve tatil ile 
ödüllendirilmesi beklentiler arasındadır. Online ürün satışı yapan firmalar müşterilerine satınalma miktarına gore verilecekleri puanlama ile; sigorta ürün/hizmet hediye imkanı sağlanabileceklerdir. Kullanıcılara sağlık, sosyal, hukuk, konut, işyeri ve araçları konusunda sigorta asistans ve bilgi hattı hizmetleri sunulabilecektir. Ayrıca dijital platform üzerinden satın alınan ürünler için sigorta yapılması da sürece olumlu katkı sağlayacaktır. Ürünün hasarlı teslim alınması riski, uygulamanın önündeki önemli bir engeldir.

\section{Pazarlama}

Pazarlama, müşteri ilişkilerinin işletme amaçlarına ulaşılmasını sağlayacak biçimde yönetilmesidir. Müşteri memnuniyetini sağlayarak mevcut müşterileri elinde tutmak ve işletme için daha değerli müşteriler haline getirmeyi, İhtiyaç ve isteklerini karşılayacak değeri vaat ederek yeni müşteriler kazanmayı amaçlar (Şanlı̈̈z vd, 2013, s.250-260).

Pazarlamanın tarihsel gelişimi incelendiğinde, işletmelerin ürün odaklılıktan tüketici odaklılığa doğru geçen bir süreç olduğu görülmektedir (Yeyeli, 2006, s.197-228). Pazarlama mantığının geçmişten günümüze dönüşümüne baktığımızda tarih boyunca değişerek geliştiğini, tüketici merkezli olduğunu görmekteyiz (Yengin ve Tezcan, 2018, s.113-123).

1900-1930 yılları arası ne üretirsem satarım fikrinin hâkim olduğu bir dönemdir. 1930-1950 yılları arası her arz kendi talebini yaratır felsefesi ile şekillenmiştir. Bu dönemde satış odaklı çalışılmış, ürünü satma becerisi ön plana çıkmıştır. 1950-1990 yılları arası kaliteli bir ürün zaten alıcı bulur fikri ön planda olmuştur (Şanlıöz, 2013, s.250-260). 1990-2000 yılları arası tüketici odaklı post modern pazarlama anlayışı gelişmiş, tüketici neyi üretmemizi istiyorsa, bizden ne talep ediyorsa onu üretiriz düşüncesiyle hareket etmişlerdir. Müşteri yakından takip edilmeye başlanmış, sürekli iletişim halinde kalınmış, memnuniyet ve sadakat düzeyleri yükseltilmeye çalışılmıştır (Yeyeli, 2006, s.197-228; Şanlıöz, 2013, s.250260). 2000'li yıllar ise klasik Pazarlama değerleri yerini gelişen elektronik sistemleri ve internet teknolojilerine bırakmaya başlamış, işletmelerin pazarlama süreçleri de bu duruma adapte edilmiştir. Grant'in balık neredeyse orada avlan dediği alışılmış pazarlama yaklaşımının tersine mobil pazarlama, balık çiftliği kurmak yaklaşımını kabul etmiştir. Mobil ve 
internet teknolojisinde kaydedilen gelişmeler zaman ile yer kısıtlarına bağlı kalınmadan hedef kitleye çabuk erişim yollarını sağlamıştır (Alabay, 2010, s.213-235; Şanlı̈̈z, 2013, s.250-260; Yeygel, 2006, s.197-228; Yengin, Tezcan, 2018, s.113-123)

\section{Mobil Pazarlama}

Mobil Pazarlama Derneği'nin tarifine göre; örgütlerin hedef kitleleri ile mobil araçlar üzerinden iletişime geçmek amacıyla gerçekleştirdikleri çeşitli etkileşimli uygulama yöntemlerine mobil pazarlama denir. Mobil pazarlama; tüketicide satınalma isteği yaratarak, mobil alan üzerinden veya mobil ürünler kullanılarak yapılan marka faaliyetleri olarak da tarif edilmektedir (Karaca ve Gülmez, 2010, s.69-81; Yengin ve Tezcan, 2018, s.113-123). Klasik pazarlama anlayışı mobil pazarlama ile bütünleşmiş, tüketici ile interaktif iletişim kurma aracı olarak kullanılmıştır (Karaca ve Gülmez, 2010, s.69-81, Şanlıöz, 2013, s.250-260). Mobil pazarlama şirketleri düzenledikleri kampanyaların daha etkili olmalarını, ürün ya da hizmetlere ilişkin yeni bir takım bilgilerin verilmesini, müşterilerin farkına varmasını, hatırlamalarını, marka imajını değiştirmeyi, markayı yeniden ve daha fazla miktarda satın almasını amaçlamaktadır (Karaca ve Gülmez, 2010; s.69-81). Mobil pazarlamanın temeli sayılan ilk faaliyetler bilgisayar dışı ortamda gerçekleştirilmiştir (Kaya, 2009). Ekonomik, bilimsel, sosyal, politik düşünüş ve yaşayış şekillerine katkı sağlayan bilgi toplumu sosyal yapının ağ toplumu haline dönüşmesi ve bilgi teknolojisinin kullanılması ile mobil pazarlama ortaya çıkmıştır (Yengin ve Tezcan, 2018, s.113-123).

Birçok ülkede dijital telefon aboneliğinin artışı internet kullanımından daha hızlı olmuştur. Mobil pazarlama mobil iletişim teknikleri yoluyla bir müşteriden diğerine reklam mesajları iletmeyi amaçlamaktadır. Yapılan çalışmalar kişisel mesajların müşteriler tarafından daha güvenilir bulunduğunu göstermiş, tanıdıkları bir kişiden mesaj alan müşterilerin mobil pazarlama kampanyalarına daha sıklıkla katıldıklarını belirlemişlerdir. Türkiye de mobil pazarlama faaliyetleri $10^{\prime}$ un üzerinde sektörde yoğunlukla kullanılmaktadır (Karaca ve Gülmez, 2010, s.69-81).

Türkiye nüfusu 2018 yılsonu itibarı ile 82 milyona yaklaşmıştır. TÜİK istatistiklerine gore ülkemizde internet kullanan bireylerin sayısı 2016 yılı itibarıyla \%76,3 olmuştur. Her on hanenin sekizi internet erişim imkânına 
sahiptir. Hanelerin $\% 96,9^{\prime}$ unda cep telefonu bulunmakta, $\% 65,2^{\prime}$ si mobil internete erişim sağlamaktadı Bu kişilerin \%34,1'i internet üzerinden alışveriş yapmaktadırlar. İnternet üzerinden yapılan alışverişlerde $\% 60^{\prime} 1$ giyim ve spor malzemesi, \%29,7'si seyahat bileti, araç kiralama vb. $\% 25,8^{\prime} \mathrm{i}$ ev eşyası (Oyuncak, mobilya, beyaz eşya vb.), \%21'i elektronik araçlar (kamera, cep telefonu, TV, radyo, DVD oynatıcı vb.), \%19,8'i gıda maddeleri ile günlük gereksinimler (tütün, kozmetik, çiçek ve içecekler) satın almışlardır. Son 3 ay içerisinde İnternet kullanan bireylerden İnterneti hemen her gün veya haftada en az bir defa kullanan bireylerin oluşturduğu düzenli İnternet kullanıcı oranı 2016 yılında \%94.9 olmuştur.

\section{Dijital Pazarlama}

Dijital pazarlama genel anlamıyla hedef pazarlara yönelik olarak internet ortamında ürünlerin geliştirilmesi, fiyatlandırılması, tutundurulması ve dağıtılmasına ilişkin stratejik bir süreçtir. Dijital araçların yoğun olarak kullanıldığı uygulamaları ifade etmektedir. Pazarlama yönetiminin temelinde bilgi, bilgiye hızlı erişim ve etkin bir bilgi yönetimi yatmaktadır (Kaya, 2009). Bilgisayar kullanımının yaygınlaşması verilerin dijital ortamda hızlı ve etkin yönetilmesini arttırmıştır. Dijital pazarlama sayesinde pazarlamanın bütün yönlerinde "müşteri ve firma" ilişkileri hızla kurulabilmekte ve yönetilebilmektedir (Kaya, 2009).

Geleneksel ve dijital pazarlamanın faklı yönleri; bilgi teknolojilerindeki gelişmeler, internetin yaygınlaşması, iş hayatının küreselleşmesi, yükselen müşteri değeri ile müşteri ilişkileri sebebiyle veri tabanı oluşturma ihtiyacının artması ve kar amacı olmayan kuruluşlarda pazarlamanın öneminin artmasıdır (Toksöz, 2010). Ekonomik faaliyetler teknolojik ilerlemelerle birlikte giderek çeşitlenmektedir (Coşkun, 2015).

İşletmeler farklı amaçlarla dolaylı ve doğrudan ihracat, lisans verme, ortak yatırım ve doğrudan yatırım yapabilmek için Uluslarasılaşma yoluna gitmektedirler. Uluslararasılaşmanın en temel yolu ihracattır. İhracat yapabilmek için işletmelerin kullandığı pazarlama yöntemlerinin başını dijital (internetten) pazarlama oluşturmaktadır (Metin, 2016, s.46974709). İlaç Sanayinde Dijital Pazarlama yöntemleri kullanıldığında; ilaç mümessillerinin takibi, ürün ve sunum performanslarının geri bildirimi, hekimlerin az zamanda doğru bilgiye ulaşması, dijital dönüşüm ile iş 
akışında zaman azaltma, anket ve formlar ile sistemin ve ürünlerin, stratejilerin sürekli gelişmesi sağlanır (Korkmaz, 2017, s.266-277).

\section{Dijital Pazarlama Adımları}

Dijital pazarlama dört basamaktan oluşmaktadır:

1. Müşteri dikkatini satışın yapıldığı ortama çekebilmek amacıyla yapılan etkinliklerdir. Arama motoru reklamları, arama motoru optimizasyonu, e-mail pazarlama, viral pazarlama, sosyal medya pazarlama, gelir ortaklığı, reklam ortaklığı, içerik üretme/paylaşma, çevrimiçi tanıtımlar bu başlık altında sayılabilir (Köse, Yengin, 2018, s.77-111).

2. Müşterinin istenilen ortama girdikten sonra satıcının hedeflerine ulaşmasına yardımcı olacak aktiviteler bu basamağı oluşturmaktadır. Dijitalleşme ve dijital teknolojiler, sosyal, kültürel, toplumsal ve ekonomik birden fazla alanı etkileme eğilimindedir. Geleneksel muadillere göre daha verimli, güçlü ve esnek olmaktadırlar. İşletmelerin daha çok insana erişebilmesi, ilgi ve gereksinimlerini karşılayacak hedef mesajları gönderebilmesi, topluluklarla gerçek zamanda iletişim kurabilmesi, toplu geri bildirim alabilmesi, kontrolün işletmelerde olması ve küçük bir bütçenin yeterli olması önemli faktörlerdendir (Köse ve Yengin, 2018, s.77111).

3. Uygulamaların yapılışlarını değerlendirilmesi ve rakiplerle karşılaştırılması açısından önemli bir adımdır. Geleneksel yöntemlere kıyasla performansı daha doğru ölçülebilmektedir. Kişiye özel ölçümler yapılabilmekte, müşteriler ve tercihleri hakkında çevrimiçi daha fazla bilgi elde edilebilmektedir (Altındal, 2013).

4. Hazır müşterileri memnun etmek ve sürekli hale getirme çalışmalarını kapsar. İyi müşteri hizmetleri sunma, E-mail pazarlama, sadakat programları dinamik fiyatlandırma stratejileri uygulama, kişiselleştirme, bu kavramın basamakları altında sayılabilir (Altındal, 2013). 


\section{İlaç Sanayinde Tanttım ve Pazarlama}

Pazarlama bir ürün veya hizmetin ilk oluştuğu andan son kullanıcıya kadar geçen sürede her basamakta değişik araçların kullanıldığı bir yönetim bilimidir. Pazarlamanın nihai amacı ilgili ürün veya hizmetin en yüksek pazar payını alarak marka bilinirliliğini en yüksek seviyeye taşıyı, ticari olarak şirketlere verim sağlamaktır. İlaç şirketlerinde zorlu pazar koşullarında mücadele edebilmek için hedef pazarlara odaklanılması, yeni pazarların bulunması, genişletilmesi, ürün yararlarının iyi anlatılması ve pazarlama harcamalarının en uygun şartlarda yapılması gerekmektedir (Civaner, 2006; İlaç Sektörü Raporu, 2016).

Dünya Sağlık Örgünün tanımına göre ilaç endüstrisinde tutundurma ilaçların reçetelenme, temin edilme, satın alınma ve/veya kullanımı arttırmak olan tüm bilgilendirici ve ikna etmeye yönelik etkinliklerdir. Türkiye İlaç Sektöründe;

Kişisel Satış ve Ürün Numunesi: Satış sunumları, doktorlar ile öğle ve akşam yemekli sunumları, ücretsiz numuneler,

Hediyeler: Sempozyumlar, paneller bilimsel yayınların basılı dağıtımı şirket gazeteleri dergi reklamları, eğlence programları, bilgisayar bağlantısı ve internet, marka ismini hatırlatıcı kalem, takvim, not defteri,

Halkla İlişkiler: Karar verici kişiler ile devlet kurumlarına halkla ilişkiler Telekonferanslar, tıbbi konulu ses, videokaset, $\mathrm{cd}$,

Reklam ve doğrudan posta: Doğrudan postalama, toplumsal amaçlı yatırımlar,

Yeni iletişim yolları: İnternet ve sosyal medya tutundurma araçları olarak kullanılmaktadır (Civaner, 2006).

Teknolojinin başlangıç noktası sayılan Endüstri Çağı insanın hayata bakış açısını değiştirmiştir. Teknoloji hayatın her alanına etki etmiş, halkla ilişkiler, reklam ve pazarlama alanında da kullanılmaya başlanmıştır. Standart kavramı tükettiği ve ürettiği ürünlere/nesnelere yansımış, yaşamını kolaylaştırmıştır. Bireyler için teknoloji nefes alıp verme gibi hayati önem taşımaya başlamıştır (Köse ve Yengin, 2018, s.77-111). Dijital devrim ise gerçek yaşamdaki eylemlerin dijital ortama taşınmasıyla başlamıştır. Dijital pazarlamanın temel dayanağı insandır. Pazarlama stratejileri üzerinde etkisini hissettiren internet, pazarlama iletişimi 
stratejisini de biçimlendirmektedir.Türkiye ilaç sektöründeki yönetmelik/ düzenlemelerden dolayı firmalar sosyal medyada sadece kurumsal bilinirliklerini destekleyecek çalışmalar yapabilmektedirler. Ödemesi sağlık bakanlığı tarafından gerçekleştirilmeyen ve ruhsatı Sağlık Bakanlığı tarafından olmayan ürünler için reklam kampanyaları düzenlenebilmektedir. Sosyal medya, kullanıcı sayılarının artması ile dijital pazarlamanın önemi önemini artmıştır (Tayız, 2014).

Türkiye İlaç Ve Tıbbi Cihaz Kurumunun (TITTCK) hukuk bölümü ilaç reklamlarının kesin olarak yasak olduğunu bildirmiştir. Buna göre 6112 sayılı kanunun anılan hükümle, reçeteye tabii olmayan ilaçlar ve tedavilerin reklamlarının dürüstlük ilkesi çerçevesinde, gerçeği yansıtan ve doğrulanması mümkün unsurlardan oluşarak hazırlananlara reklamlara imkân yolu açmış olsa da bu alanda özel Kanun niteliği taşıyan 1262 sayılı kanuna (İspençiyari ve Tibbi Müstahzarlar) göre ilaçların reklamı mümkün olamamaktadır. Ancak reçetesiz ürünlerin reklamının kesinlikle yasak olduğunu belirtir bağlayıcı hüküm yoktur (Resmi Gazete, 19279, s.901-910). Bu açık durumdan ötürü ülkemizde Takviye Edici Gıda statüsünde olan vitamin ve vitamin kombinasyonları, bebek mamaları ile dermokozmotik ve CE belgeli suni gözyaşı ürünleri internet ortamında tanıtımı ve satışı yapılmaktadır ayrıca birçok vitamin ve bebek mamasının Televizyon reklamları yayınlanmaktadır.

Teknolojinin başlangıç noktası sayılan Endüstri Çağı insanın hayata bakış açısını değiştirmiştir. Teknoloji hayatın her alanına etki etmiş, halkla ilişkiler, reklam ve pazarlama alanında da kullanılmaya başlanmıştır. Standart kavramı tükettiği ve ürettiği ürünlere/nesnelere yansımış, yaşamını kolaylaştırmıştır. Bireyler için teknoloji nefes alıp verme gibi hayati önem taşımaya başlamıştır (Köse ve Yengin, 2018, s.77-111). Dijital pazarlamanın temel dayanağı insandır. Pazarlama stratejileri üzerinde etkisini hissettiren internet, pazarlama iletişimi stratejisini de biçimlendirmektedir.Türkiye ilaç sektöründeki yönetmelik/ düzenlemelerden dolayı firmalar sosyal medyada sadece kurumsal bilinirliklerini destekleyecek çalışmalar yapabilmektedirler. Ödemesi sağlık bakanlığı tarafından gerçekleştirilmeyen ve ruhsatı Sağlık Bakanlığı tarafından olmayan ürünler için reklam kampanyaları düzenlenebilmektedir sosyal medya, kullanıcı sayılarının artması ile dijital pazarlamanın önemi önemini artmıştır (Tayız, 2014). 


\section{Dijital Pazarlamada Verilebilecek Sigorta Hizmetleri}

Dijital pazarlamada verilecek sigorta hizmetleri 3 şekilde olabilmektedir. Bunları satınalınan ürün için yapılan nakliyat sigortası, kullanıcıya yönelik ferdi kaza sigortası ve asistans hizmetleri sınıflandırabiliriz. Sigorta teknik olarak; hayatımızdaki risklerin gelecekte bizlerin can, mal ve sorumluluklarında oluşturcağı zarar ve hasarlar için önceden prim ödeme kaydı ile oluşan bir güvence sistemidir (Özcan, 2018). Sistemin özünde zaraları ortak karşılama mantığı bulunmaktadır. Dolayısı ile yukarıda bahsi geçen sigorta uygulamaları için sigorta havuzuna prim girişi şarttır. Prim ödeme yükümlügü dijital platformlarda satış yapan ilaç satıcılarına ait olacaktır. Prim olmadan sigorta sisteminden bahsedilemez.

Nakliyat sigortası satınalınan ürün için yapılabilecek bir police türüdür. Ürünün siparişinden müşteriye teslimine kadar geçen sürede başına gelebilecek hasar ve kayıp teminatını içerir. Bu hizmetin hediye olarak müşterilere verilmesinin satış artışında önemli bir etkisi olabilecektir.

Ferdi kaza sigortası ise sistemi kullanan kişilere yönelik bir can sigortası türüdür. Vefat, tedavi ve maluliyet teminatları vardır. Bu hizmet bir meblağ sigortası türüdür; yani riskmin gerçekleşmesi durumunda poliçe şartlarına göre ödeme yapılacaktır. Bu hizmetteki en önemli detay ise teminatın miktarıdır. Bu miktar ne kadar ise riskin gerçekleşince o kadar ödeme yapılır. Örneğin vefat teminatı poliçede 5.000 TL ise ölüm durumunda bu bedel ödenecektir. Aynı şekilde teminat 500.000 TL ise ölüm durumunda 500.000 TL ödenecektir. Maluliyet durumunda ise police genel şartlarında vücudun organları için farklı sakatlık oranları vardır.

Asistans hizmetlerini ise kişiye, konuta/işyerine destek ve hizmet hatları olarak çeşitlendirebiliriz. Kişiye yönelik olanlar ise ücretsiz ambulans, acil doktor, check-up ve ilk tıbbi müdahale hizmetleridir. Konuttaki asistans hizmetleri ise acil durumlarda ücretsiz su tesisat, elektrik tesisat, cam ve çilingir desteğidir. Bu hizmetler sigortalılara 365 gün 24 saat verilmektedir. Gece ilerleyen bir saatte konutunun anahtarını kaybetmiş bir kişi için çilingir hizmeti çok önemli bir yardım uygulamasıdır. Aynı şekilde araçlar için çekme, çekilme, kurtarma, akü bitmesi, lastik değiştirme, benzin bitmesi, kaza sonrası ulaşım masrafları, konaklama vb hizmetleri içermektedir. Bahsi geçen tüm bu hizmetlerin sınırsız değildir 
ve yapılan sözleşmeye gore limitleri vardır. Bazı hizmetlerde ise bir limit yoktur ve bunlar telefon ile yapılan danışma talepleri teminatları olup; hukuki danışma, tıbbi danışma, bilgi alma hatları, rezervasyon sistemleri, araç kiralamada aracılık, adrese yönlendirme ve anlaşmalı kurumlarda indirim hizmetlerini kapsamaktadır.

\section{Araştırma}

\section{Literatür}

Günümüzde sigorta şirketleri için ürün ve hizmetlerin pazarlanmasında müşterilerle gittikçe daha fazla dijital iletişim kurmak önem kazanmaktadır. Bu çağ sigorta sektöründe dijital çă̆ olarak bahsedilmektedir. Yapılan araştırmalar sigorta sektörü için dijital dönemin başladığına dikkat çekmektedir. Çalışmanın amacı hayat dışı sigorta şirketlerinin dijital sigorta uygulamalarını araştırmaktır. Çalışmada Türkiye'de faaliyet gösteren 38 hayat dışı sigorta şirketinin internet siteleri incelenerek dijital sigorta uygulamasında hangi seviyede oldukları tespit edilmeye çalışılmıştır. Bazı sigorta şirketleri gelişmiş dijital sigorta uygulamaları sunarken, bazı şirketlerde dijital uygulamalar bulunmamaktadır (Yuldakul ve Dalkılıç, 2016).

İstanbul'da faaliyet gösteren ve JCI (Joint Commission International) akreditasyonu almış olan hastanelerin uluslararası kapsamda sağlık turistlerine ulaşmak amacıyla yürüttükleri dijital iletişim çalışmalarının ortaya konulması amacı bir çalışma yapılmıştır. Araştırma bulgularına göre hastanelerin dijital iletişim kanallarında farklı dallarda verdikleri hizmetler, başarıları, hekimlerinin katıldıkları bilimsel toplantılar, ek hizmetler, sunulan ulaşım destekleri gibi konularda bilgi aktarımı yaptıkları, fotoğraf ve video paylaştıkları belirlenmiştir. Ancak hastanelerin dijital iletişimin etkileşim kurma olanağından yeterince faydalanamadığ 1 saptanmıştır. Analiz sonuçlarına göre, dijital iletişim kanalları sağlık turizminde bir bilgi aktarım aracı olarak kullanılmaktadır (Öksüz ve Altıntaş, 2017).

Gelecekte büyüme trendi gösteren Türk Sigorta Sektörünü incelemek, sektörün büyümesinin önündeki fırsat ve engelleri tespit etmek amacı ile bir araştırma hazırlanmıştır. Bu amaçla araştırmacı, sigorta sektörünün 
neden ortaya çıktı̆̆ı, nasıl geliştiği ve poliçe sahibine sunduğu ayrıcalıkları işleyecektir. Türk Sigorta Pazarını, dünyadaki ve Avrupa'daki sigorta pazarları ile kıyaslanmıştır. Günümüzde birçok sektörde trend haline gelmiş dijital dönüşüm trendlerinin sigorta sektöründe yapılan ve yapılacak uygulamaları işlenmiştir Bulut teknolojisi, akıllı mobil cihazlar, nesnelerin interneti, insansız hava araçları ve yapay zeka gibi gelişmelerin sektöre sağlayacağı faydaları incelenmiştir. Tüm gelişmeleri Türk Sigortacıllğı ve acenteler tarafından değerlendirerek, dijital dönüşümün Türk Sigortacılığında uygulanma biçimlerini gözlemlenmiştir (Özyalçın, 2017).

\section{Araştırmanın Evreni}

Araştırmanı evreni İstanbul ilinde ilaç sektöründe çalışan doktor, hemşire lerden oluşmaktadır. Örneklemi ise, katılımcılar arasından basit tesadüfi örnekleme ile seçilen kişilerden oluşmaktadır.

\section{Araştırma Metodolojisi}

Literatür taramaları sonrası oluşturulan “İlaç Sektörünün Dijital Pazarlamaya Geçişte Mevcut Alışkanlıklarının Yeni Sisteme Adaptas yonu Üzerine Bir Araştırma" isimli anket formu Google Drive aracılığ 1 ile anket çalışmasına katılmak isteyen kişiler ile paylaşılmıştır.

Çalışmaya başlanmadan önce 5 kişi ile ön çalışma yapılmıştır. Yapılan çalışma ile soruların anlaşılma düzeyleri değerlendirilmiştir. Ön çalışma sonrası soruların anlaşılır olduğu, revizyon gerektirmediği belirlenmiş anket çalışmasına başlanmıştır.

Araştırmada verilerin toplanması için deneklere kapalı uçlu ve açık uçlu sorular sorulmuştur. Açık uçlu sorulara verilen cevaplar kendi içlerinde sınıflandırılmıştır. Araştırmaya 102 kişi katılmış olup; elde edilen verilerin analiz edilmesinde SPSS 22.0 paket programı kullanılmıştır. Normallik analizi olarak Kolmogorov Smirnov testi kullanılmıştır.

Araştırma üç bölümden oluşmaktadır. İlk bölüm 4 soruluk sosyo demografik özelliklere yönelik yaş, cinsiyet, eğitim durumu, iş/meslek bilgilerini içeren sorulardan oluşturulmuş, ikinci bölüm dijital İletişim/ dijital 
Pazarlama ile ilgili gün içinde toplam internet kullanım süresi, gün içinde iş için kullanılan internet süresi, internetten alışveriş yapmayı güvenli bulma durumu, kongre/bilgi şöleni ve eğitimlerin internet üzerinden canlı yayınlanması, (tek şık seçerek cevap verecekleri soru grubunu) İnternetten pazarlama faaliyetlerinde ürün hakkında bilgi vermek için sosyal medyanın kullanılması (faydalı olur, faydası olmaz, olumlu ya da olumsuz katkı sağlamaz seçeneklerinin sunulduğu 3'lü likert), internetten satın alınan ürünler (birden fazla şık seçebilecekleri soru grubu) toplam 7 sorudan oluşturulmuştur. Üçüncü bölüm ilaç sanayinde dijital pazarlama hakkında fikirlerinin sorulduğu; ilaç sanayinde pazarlama faaliyetlerinde herkesin ulaşabileceği reklam, video ve görseller kullanılabilir, sosyal medyada tanımlanmış hedef kitlenin ulaşabileceği sınırlı içerik paylaşımı, ürün lansmanı firmanın internet sitesi / sosyal medya aracilığıyla çevrimiçi yapılabilmeli (faydalı olur, faydası olmaz, olumlu ya da olumsuz katkı sağlamaz seçeneklerinin sunulduğu 3'lü likert), ilaç pazarlamasında dijital yöntemlerin kullanılmasının olumlu yanları, ilaç pazarlamasında dijital yöntemlerin kullanılmasının olumsuz yanları, dijital pazarlamayı arttırmak için neler yapılabilir (açık uçlu) soruların sorulduğu ve verilen cevapların kendi içinde gruplandırıldığı toplam 18 sorudan oluşmuştur. Araştırma öncesi 5 kişi ile ön çalışma yapılmıştır. Yapılan çalışma ile soruların anlaşılma düzeyleri değerlendirilmiştir. Ön çalışma sonrası soruların anlaşılır olduğu, revizyon gerektirmediği belirlenmiş anket çalışmasına başlanmıştır.

Yaş, cinsiyet, eğitim durumu, meslek durumu băğımsız değişken, gün içinde toplam kullanılan internet süresi, gün içinde iş için kullanılan internet süresi, internetten alışveriş yapmayı güvenli bulma durumu, internetten satın alınan ürünler, pazarlama faaliyetlerinde sosyal medya kullanımı, herkesin ulaşabileceği reklam/ video/ görsel kullanımı, sosyal medyada tanımlanmış hedef kitlenin ulaşabileceği sınırlı içerik paylaşımı, online ürün lansmanı, kongre/sempozyumların internetten canlı yayınlanma durumu, pazarlama faaliyetlerinin dijital yapılması için gerekli düzenlemeler, ilaç pazarlamasında dijital yöntemlerinin kullanılmasının olumlu yanları, ilaç pazarlamasında dijital yöntemlerinin kullanılmasının olumsuz yanları, dijital pazarlamayı arttırmak için neler yapılabilir bağımlı değişken olarak alınmıştır 
$\mathrm{Bu}$ araştırma dijital pazarlamanın ilaç sanayinde kullanılabilmesi için ihtiyaç duyulan düzenlemelerin saptanması ve pazarlamanın hangi aşamalarında kullanabileceğimizi belirlemek amacıyla yapılmıştır. Araştırma sonucunda dijital pazarlamanın olumlu, olumsuz yanları, mevcut durumun tespiti ve geleceğe yönelik planlama tespitleri bulunmaktadır.

\section{Araştırmanın Bulguları ve Analizi}

Çalışmaya katılan kişilere "pazarlama faaliyetlerinin dijital yapılabilmesi için nasıl düzenleme yapılmalı" şeklinde fikirleri sorulduğunda 29 kişi görüş bildirmemiş, 5 kişi $(\% 4,7)$ pazarlamada insan faktörünün kaldırılamayacağ1 yönünde görüş bildirmiş, 68 kişi toplam 107 farklı cevap/öneride bulunmuştur. Sağlık profesyonelleri için şifreli dijital programlar (mail, sms, ipad) geliştirilmesini öneren 26 kişi, (\%24,3), Reklam serbestisi getirilmesini öneren 20 kişi, (\%18,8), hasta/sağllk profesyoneli dışındaki tüketiciyi bilinçlendirme/ bilgilendirme ve korunmasını önren 16 (\%15), yasal düzenlenme yapılmasını öneren 12 kişi (\%11,2), çevrimiçi sunumlar oluşturulmasını öneren 6 kişi $(\% 5,6)$ firmaların kendi dijital veri güvenliğini koruma programlarını oluşturmaları öneren 6 kişi $(\% 5,6)$, sosyal medyanın iletişim gücünden yararlanılmasını öneren 5 kişi $(\% 4,7)$ dijital pazarlama faaliyetlerinin bağımsız kuruluşlarca denetlenebilmesini öneren 4 kişi $(\% 3,7)$,pazarlaması yapılan ürünün orijinalliğini gösteren uygulamaların kullanılmasını öneren 3 kişi (\% 2,8), yetkisi olmayan kişilerin pazarlama yapmamasını öneren 1 kişi (\% 0,9), dijital pazarlamada kısıtlayıcı unsurların kullanılmaması öneren 1 kişi $(\% 0,9)$, sağlık profesyonellerinin dijital pazarlama hakkında görüş ve önerilerinin araştırılmasını öneren 1 kişi (\% 09), tüm pazarlama faaliyetleri herkesin erişimine açı hale gelmesini öneren 1 kişi $(\% 0,9)$ olmuştur.

Çalışmaya katılan kişilere "İlaç pazarlamasında dijital yöntemlerin kullanılmasının olumlu yanları sorulduğunda 12 kişi görüş bildirmemiş, 90 kişi toplam 129 farklı cevap vermiştir. Hedef kitleye hizlı erişim sağlanacağını belirten 52 kişi $(\% 40,4)$, zaman ve finans kontrolünün etkin yapılacağını belirten 18 kişi (\%13,9), daha az maliyetle daha çok kişiye ulaşım sağlanacağını belirten 14 kişi $(\% 10,8)$, bilinçli hastaların tedaviye erişimini artıracağını belirten 12 kişi $(\% 9,4)$, marka bilinilirliğinin artışını 
sağlayacağını belirten 9 kişi $(\% 6,9)$, çağı yakalaması 8 kişi $(\% 6,3)$ bilgilerin hedef kitleye göre kişiselleştirilmesinin sağlanabilmesi 7 kişi $(\% 5,4)$, bilgiye kesintisiz erişim sağlanabilmesi 7 kişi $(\% 5,4)$ ve satışı artırması 2 kişi $(\% 1,5)$ yanıtlarını vermiştir.

Çalışmaya katılan kişilere "dijital pazarlamayı arttırmak için neler yapılabileceği sorulduğunda 35 kişi görüş belirtmemiş, 67 kişi 110 farklı görüş belirtmiştir. Sağlık profesyonellerinin erişebileceği resmi internet siteleri ve uygulamalar kurulmasını öneren 15 kişi (\%13,7), Halk eğitim ve bilgilendirme toplantıları öneren 13 kişi $(\% 11,9)$ dijital sektör dilinin oluşturulmasını öneren 12 kişi $(\% 10,9)$, reklam yapılmasını öneren 12 kişi $(\% 10,9)$, sağlık profesyonellerine eğitimler verilmesini öneren 10 kişi $(\% 9,2)$, yasal düzenleme yapılmasını 9 kişi $(\% 8,2)$, şirketler tarafından sosyal medyanın etkin kullanımını öneren 8 kişi $(\% 7,3)$, yazılı pazarlama içeriğinin oluşturulmasını öneren 7 kişi $(\% 5,5)$, kongre ve sunumların canlı yayınlanmasını öneren 4 kişi $(\% 3,7)$, internet erişim engellerinin çözülmesi ve ucuzlatılması 4 kişi $(\% 3,7)$, firmaların sponsorluk katkılarını arttırılmasını öneren 3 kişi $(\% 2,8)$, ürünlere dijital barkod verilmesini öneren 2 kişi (\%1,9), sigortalama yapılmasını öneren 57 kişi (\% 51,9), hedef kitlenin erişim zamanının belirlenmesini öneren 2 kişi $(\% 1,9)$, internet sitesi güvenlik tedbirlerinin oluşturulmasını öneren 2 kişi (\%1,9, dijital pazarlama için bütçe 2 kişi $(\% 1,9)$, ulaşımı zor yayınların dijital ortamda yayınlanmasını öneren 1 kişi $(\% 0,9)$, firmaların rekabet ortamı oluşturmadan tanıtım yapmalarına izin verilmesini öneren 1kişi $(\% 0,9)$ ve dijital sektör için ayrı çalışan istihdam edilmesini öneren 1 kişi $(\% 0,9)$ olmuştur.

Dijital pazarlamayı arttırabilmek için neler yapılabileceği sorusuna verilen cevaplarda; katılımcllıların yaklaşık yarısı sigorta hizmetinin faydalı olabileceğini belirtmiştir.

\section{Sonuç / Öneriler}

Araştırmaya 51 kadın (\%50), 51 erkek (\%50) katılmıştır. En küu̧üğü 24 yaşında, en büyüğü 58 yaşında, yaş dağılımı 30-35 yaş aralığında toplanmış yaş ortalaması 38,6 yaştır. Eğitimde 55 kişi $(\% 53,8)$ lisans mezunu, 26 kişi $(\% 25,5)$ tanıtım temsilcisi/uzmanı, 82 kişi $(\% 86,4)$ İlaç sanayinde çalışmaktadır. 
Araştırmaya katılan kişilerin büyük çoğunluğu gün içinde toplamda 6 saat ve üzerinde internet kullanmakta,iş için internet kullanma süresi 1 saatten az 24 kişi $(\% 23,5)$ ve 2-4 saat arasında iş için internet kullanımı 24 kişi $(\% 23,5)$ yoğunluk göstermektedir. 77 kişi $(\% 75,5)$ internetten alış veriş yapmayı güvenli bulmakta, 5 kişisi $(\% 4,9)$ internetten hiç alış veriş yapmadığını belirtmekte, 68 kişi $(\% 36,4)$ giyim/kozmetik ürün alışverişi internetten en fazla satın alınan ürünler arasında olduğu belirtilmektedir.

84 kişi $(\% 82,4)$ kongre ve sempozyumların internetten canlı yayınlanması faydalı olacağını düşünmekte, 85 kişi $(\% 83,3)$ İlaç pazarlama faaliyetlerinde sosyal medya kullanımının faydalı olacağını düşünmekte, 74 kişi $(\% 72,6)$ ürün lansmanın online yapılabilmesi gerektiğini, 69 kişi $(\% 67,7)$ Pazarlama faaliyetlerinde görsel, video ve reklamların sınırlı hedef kitle ile paylaşılmasının uygun olacağını belirtmiştir

Bireylerin cinsiyetleri ile faktörlerin karşılaştırılmasında; Gün İçinde İş İçin Kullanılan İnternet Süresi, İnternetten Alış Veriş Yapmayı Güvenli Bulma, Pazarlama Faaliyetlerinde Sosyal Medya Kullanımı, Herkesin Ulaşabileceği Reklam/ Video/ Görsel Kullanımı, Sosyal Medyada Tanımlanmış Hedef Kitlenin Ulaşabileceği Sınırlı İçerik Paylaşımı ve Dijital Pazarlamayı Arttırmak İçin Neler Yapılabilir faktörleri istatiksel olarak anlamlı bulunmuştur. $(\mathrm{p}<0,5)$

Bireylerin yaş durumları ile faktörlerin karşılaştırılması İnternetten Alış Veriş Yapmayı Güvenli Bulma, Pazarlama Faaliyetlerinde Sosyal Medya Kullanımı, Herkesin Ulaşabileceği Reklam/ Video/ Görsel Kullanımı, Sosyal Medyada Tanımlanmış Hedef Kitlenin Ulaşabileceği Sınırlı İçerik Paylaşımı ve Dijital Pazarlamayı Arttırmak İçin Neler Yapılabilir faktörleri istatiksel olarak anlamlı bulunmuştur. $(\mathrm{p}<0,5)$

Bireylerin eğitim durumları ile faktörlerin karşılaştırılmasında; Gün İçinde Kullanılan Toplam İnternet Süresi, Gün İçinde İş İçin Kullanılan İnternet Süresi, İnternetten Alış Veriş Yapmayı Güvenli Bulma, İnternetten Satın Alınan Ürünler Pazarlama, Faaliyetlerinde Sosyal Medya Kullanımı, Sosyal Medyada Tanımlanmış Hedef Kitlenin Ulaşabileceği Sınırlı İçerik Paylaşımı, Kongre ve Sempozyumun İnternetten Canlı Yayınlanma Durumu, Pazarlama Faaliyetlerinin Dijital Yapılması İçin Gerekli Düzenlemeler, İlaç Pazarlamasında Dijital Yöntemlerinin Kullanılmasının Olumlu Yanları ve Dijital Pazarlamayı Arttırmak İçin Neler Yapılabilir faktörleri istatiksel olarak anlamlı bulunmuştur. $(p<0,5)$ 
Bireylerin meslek durumları ile faktörlerin karşılaştırılmasında; İnternetten Alış Veriş Yapmayı Güvenli Bulma, İnternetten Satın Alınan Ürünler Pazarlama, Faaliyetlerinde Sosyal Medya Kullanımı, Online Ürün Lansmanı, Kongre ve Sempozyumun İnternetten Canlı Yayınlanma Durumu, Pazarlama Faaliyetlerinin Dijital Yapılması İçin Gerekli Düzenlemeler, İlaç Pazarlamasında Dijital Yöntemlerinin Kullanılmasının Olumlu Yanları ve İlaç Pazarlamasında Dijital Yöntemlerin Kullanılmasının Olumsuz yanları faktörleri istatiksel olarak anlamlı bulunmuştur $(\mathrm{p}<0,5)$.

Elde ettiğimiz sonuçlar doğrultusunda; pazarlama faaliyetlerinde insan faktörü kilit noktada yer almakta, yüz yüze iletişimin dijital tekniklerle desteklenmesi gerektiği, uygun yasal ve dijital düzenlemeler yapılarak ilaç pazarlama faaliyetlerinde reklam yapılmasının önünün açılmasının sağlanması, müşteri tecrübelerini tüm yönleriyle ele alınması gerekmektedir. Dijital platformlarda güvenlik sorunları ile karşılaşmamak için uygun yazılımın programlanması, şifrelenmesi ve yetkilendirilecek kişilerin erişiminin sağlanmalıdır. Dijital teknikleri kullanma konusunda tanitım temsilcisi/uzmanına kota verilmesi ve kotasına uygun sıklıkla kullanan temsilcinin puan, giyim çeki, prim ve tatil ile ödüllendirilmesi, online ürün satışı yapan firmaların ödül puan veya online satış artırıcı uygulamalar yapması, eczacı ve temsilciye verilecek puan karşılığı sigorta şirketlerinden ürün/hizmet kişilere hediye edilebilir. Hediye edilecek ürünler; Araç ile ilgili; Araç bilgi hattı, çekme, kurtarma, araca çilingir gönderme hizmeti, profesyonel sürücü hizmeti, lastik değiştirme hizmeti, benzin bitmesi, tıbbı nakil, konaklama, lehdarın seyahatinin tamamlanması, Konut/İş yeri ile ilgili; su ile elektrik tesisatı işleri, cam ve çilingir işleri, Sosyal yardım hizmetleri; bil gilendirme hattı, sosyal aktivite ile ilgili bilet alımı /rezervasyon /ulaştırma, otel ile araç rezervasyonları Sağlık Hizmetleri; Estetik ile güzellik bakım hizmeti ve diş checkup hizmeti, ergen checup hizmeti, online alışveriş yapan tüketicilere alacakları puana göre hediye verilebilir. 


\title{
EXTENDED ABSTRACT \\ A Study on The Effect of Use of Insurance Products on Digital Marketing
}

\author{
* \\ Hakan Özcan - Gökhan Demiral \\ Okan University
}

Marketing is the management of customer relations in such a way as to achieve business objectives. It aims to gain new customers by promising customer satisfaction, to retain existing customers and to make them more valuable customers for the enterprise, by promising value to meet their needs and demands. Mobile marketing; various interactive application methods that mobile businesses perform to communicate with their target audience via mobile tools are called mobile marketing. Mobile marketing; it is also defined as brand activities by using the mobile area or by creating mobile products. Digital marketing is a strategic process for the development, pricing, distribution and distribution of products on the internet in general. It refers to applications where digital tools are used extensively.

Marketing management is based on information, rapid access to information and effective information management. Developing and changing technology has been used effectively in every aspect of our life. The pharmaceutical sector in our country has also developed in parallel with global changes. With the increasing use of social networks, new opportunities have emerged in terms of marketing and sales techniques. In our country, it is forbidden to sell and sell medical products in digital media. However, companies that market reinforcement medicines and herbal medicinal products aim to sell with digital marketing. In this study, it has been researched what should be done in order to use digital marketing effectively in pharmaceutical industry. The impact of insurance on the marketing process and the use of insurance products were analyzed. Field research was conducted among the pharmaceutical and health sector employees. The questionnaire titled e a research on the adaptation of the existing habits of the pharmaceutical sector to digital marketing, which was created after the literature reviews, was shared with the people who wanted to participate in the survey via google drive. The research consists of three parts. 
The first part consisted of questions about age, gender, educational status, job / profession information about socio-demographic characteristics. The second part digital communication / digital marketing to provide information about the product during the day, total internet usage time, the internet time used for business during the day, safe online shopping status, congress / information feast and live broadcasting of trainings over the internet, internet marketing activities the use of social media is composed of 7 questions about products purchased from the internet. The third part is asked about their ideas about digital marketing in pharmaceutical industry; advertising, video and images can be used in marketing activities in the pharmaceutical industry, limited content sharing accessible to the target audience defined in the social media, product launch can be made online through the company's website / social media, in addition, 18 questions were asked about what can be done to increase digital marketing (open-ended) questions and grouped in the answers given.

Pre-study was performed with 5 people before the study. The level of understanding of the questions was evaluated with the study. In the study; age, gender, educational status, occupational status were taken as independent variables. The positive aspects of using digital methods in pharmaceutical marketing are the negative aspects of using digital methods in pharmaceutical marketing, what can be done to increase digital marketing as a dependent variable. The answers to open-ended questions were classified within themselves. 102 people participated in the study; SPSS 22.0 package program was used to analyze the data obtained. This research was carried out to determine the necessary arrangements for the use of digital marketing in the pharmaceutical industry and to determine the stages of marketing. As a result of the research, there are positive and negative aspects of digital marketing, determination of current situation and planning for future. In the answers given to the question of what can be done to increase digital marketing; approximately half of the respondents stated that the insurance service could be useful. A number of incentives have been identified for the effective use of digital marketing. It is expected that users will be rewarded with points, clothing checks, premiums and holidays.

The companies that sell online products will be given to customers according to the amount of purchase by scoring; provide insurance service 
alternative. We will be able to provide insurance assistance and information line services to users on health, law, housing, workplace and vehicles. Insurance for products purchased through the digital platform will also contribute positively to the process. The risk of receiving a product in a damaged manner is one of the most important obstacles in the development of this type of marketing.

\section{Kaynakça / References}

Altındal, M., (2013). Dijital pazarlamada marka yönetimi ve sosyal medyanın etkileri, XV. Akademik Bilişim Konferansı Bildirileri,içinde (AB 13, II.Cilt), 23-25 Ocak 2015, Antalya.

Alabay, M.N. (2010). Geleneksel pazarlamadan yeni pazarlama yaklaşımlarına geçiş süreci, Süleyman Demiral Üniversitesi, İktisadi ve İdari Bilimler Fakültesi Dergisi, 15 (2), 213-235.

Civaner, M. (2006). İlaç şirketlerinin pazarlama yöntemleri ve hekimlere etkileri: Medikal Etik. İstanbul:Yüce Yayım.

Ekiyor, A. ve Tengilimoğlu, D. (2014). Sağlıta reklam serbest olmalı mı? Tüketici görüşleri, Gazi Üniversitesi İktisadi ve İdari Bilimler Fakültesi Dergisi 16(2), 45-71.

Ercan, T., ve Top, M. (2016). İlaç tanıtım pazarlama faaliyetlerinin önemi, Cumhuriyet Üniversitesi Sağlık Bilimler Enstitüsü Dergisi, 2(1), 1-7.

Karaca, Ş., Gülmez, M. (2010). Mobil pazarlama: Kavramsal bir değerlendirme, Akademik Yaklaşımlar Dergisi, 1 (1), 69-81.

Korkmaz, S., Mansur, F. ve Uslu, D., (2017). Dijital ilaç pazarlama uygulamaları geleneksel uygulamaları yıkıyor mu? Hekimlere yönelik bir araştırma, Uluslararası Sağlık Yönetimi Ve Stratejileri Araştırma Dergisi, 3, 266-27.

Köse, N. ve Yengin, D. (2018). Dijital pazarlamadan fijital pazarlamaya geçişe örnek olarak arttırılmış gerçeklik ve sanal gerçeklik uygulamalarının pazarlama üzerindeki katkılarının incelenmesi. İstanbul Aydın Üniversitesi Dergisi - İÄ̈D, 10 (1), 77-111.

Kurt, M. (2016). İşletmecilik tarihi: Özel sayıya giriş, İstanbul Üniversitesi İşletme Fakültesi Dergisi, 45, Özel Sayı, 2-8.

Metin, İ. (2016). Dijital pazarlama araçlarının KOBİlerin ihracatına etkisi. Journal of Human Sciences, 13(3), 4697-4709 
Şanlı̈z, H.K., Dilek, E. ve Koçak, N., (2013). Değişen dünya, dönüşen pazarlama: Türkiye turizm sektöründen öncü bir mobil uygulama örneği, Anatolia- Turizm Araştırmaları Dergisi, 24 (2),250-260.

Şenses. O., (2016). Etkinlilik, Power Point Sunusu, Karadeniz Teknik Üniversitesi

Öksüz, B. ve Altıntaş, V. (2017). Sağlık turizminde dijital iletişim kanallarının kullanımı, Seyahat ve Otel İşletmeciliği Dergisi, 14(1), 59-75.

Özcan, H. (2018). Sigorta acenteleri, İstanbul:Kriter Yayınları,

Özyalçın, Z. (2017). Türk sigorta sektörünün gelecek perspektifi, Yüksek Lisans Tezi, İstanbul Ticaret Üniversitesi, İstanbul.

Yengin, D. ve Tezcan, E.T. (2018). Halkla ilişkilerin dijitalleşmesi bağlamında konum tabanlı pazarlama. Istanbul Aydın Üniversitesi Dergisi, 10 (1), 113-123.

Yurdakul, M. ve Dalkılıç, N. (2016). Sigorta sektöründe dijital çağ. Dumlupınar Üniversitesi Sosyal Bilimler Dergisi, 50, 49-67.

\section{Kaynakça Bilgisi / Citation Information}

Özcan, H. ve Demiral, G. (2019). Sigorta ürünlerinin dijital pazarlamaya etkisi üzerine bir araştırma. OPUS-Uluslararası Toplum Araştırmaları Dergisi, 11(18), 2087-2107. DOI: 10.26466/opus.558980. 